Review

\title{
Educational Approaches to Encourage Pro-Environmental Behaviors in Madagascar
}

\author{
Dominik Schüßler*(D), Torsten Richter and Jasmin Mantilla-Contreras \\ Research Group Ecology and Environmental Education, University of Hildesheim, Universitaetsplatz 1, \\ 31141 Hildesheim, Germany; richtert@uni-hildesheim.de (T.R.); mantilla@uni-hildesheim.de (J.M.-C.) \\ * Correspondence: dominik.schuessler@posteo.de; Tel.: +49-17657664530
}

Received: 13 April 2019; Accepted: 31 May 2019; Published: 4 June 2019

\begin{abstract}
Madagascar is a biodiversity hotspot under threat, with about $80 \%$ of the population living below the poverty line and dependent on the use of diminishing local resources. Environmental education (EE) can act as an important tool for biodiversity conservation, however, its implementation is challenging in low-income countries. Here, we provide a review of $248 \mathrm{EE}$ interventions throughout Madagascar. We highlight how EE can promote pro-environmental behaviors and show the major obstacles it faces, using Madagascar's Lake Alaotra as a case study area. All EE activities are implemented by non-governmental organizations (NGOs) and international institutions. EE and community engagement have been shown by practitioners and scientific research alike to be valuable tools but are severely restricted in their impact when their outreach is limited by insecure and insufficient funding, and often funding periods that are too short. Another major hindrance to EE producing positive changes in people's real-life decisions in low-income countries like Madagascar, arises when lessons are taught to a population that is at once understanding and severely constrained in its choices due to poverty, and corresponding malnutrition, that forces people to make unsustainable decisions on a daily basis. Our conclusions should help to improve the practice of EE in Madagascar and other low-income countries.
\end{abstract}

Keywords: environmental education; low-income countries; biodiversity conservation; Lake Alaotra

\section{Introduction}

Madagascar is a diverse country in many ways. The world's fourth biggest island, and conservation hotspot, is well-known for its richness of species and outstanding degree of endemism [1,2]. Historically, the Malagasy population was formed by settlers from Indonesia, the African mainland, and Arabic trader communities, resulting in a multitude of at least 18 different ethnic groups that are deeply rooted in local culture, traditional beliefs, and rituals (e.g., [3,4]).

Despite its biological and cultural diversity, Madagascar is among the poorest countries in the world with approximately $78 \%$ of the population living in extreme poverty with an average income of less than US\$2 per day [5]. As about $65 \%$ of the Malagasy population is confined to rural settings, with restricted access to infrastructure and cross-regional markets [5], the dependence on local resources is high $[4,6]$. Traditional methods of crop farming and game hunting have been identified as being unsustainable given the recent development of strong population growth [5,7-9], and consequently, biodiversity and human livelihoods are under threat. An increasing demand for arable land is fueling deforestation and degradation of natural ecosystems [7,10]. Additionally, the over-exploitation of wildlife, so-called "bushmeat hunting", is contributing to the decline of many species [11-13]. Despite receiving hundreds of millions of US dollars from international donors over the last fifteen years for environmental projects alone, ecological issues are prevalent all over the island. Unsustainable 
resource use, deforestation and habitat degradation facilitate erosion, changes in local climates, and the loss of livelihoods, especially in rural areas [7,10,14,15].

In order to foster biodiversity conservation, a broad consensus on the role of environmental education (EE) in teaching people from all ages about the biophysical environment, associated problems and possible solutions by encouraging pro-environmental behaviors has been built during the last few decades [16-19]. EE has been successfully used in biodiversity conservation programs in different settings and countries throughout Africa [20-22]. It is closely linked to a country's system of formal education. In Madagascar, this system is in constant evolution and is currently divided into six years of compulsory primary school education and another four and three years of junior and senior secondary school education, respectively. Each level of schooling is successfully completed by passing the respective final examination which then allows students to apply for the next level of schooling [23]. Attendance at secondary schools, applied colleges, and universities is voluntary and is particularly a privilege for children from urban areas with parents who can afford school fees. In general, there is a marked decline of education options from (large) cities to rural villages [24]. The expected number of years of schooling is 10.5 years whereas the actual mean duration of schooling is about 6.1 years; 6 out of 10 students leave primary school without taking the final examinations [5] while only $3 \%$ complete secondary school education $[25,26]$. For an in-depth description of the Malagasy school system and its challenges see Reibelt et al. [25]. However, in strong contrast to Western education experience, universities are usually the first opportunity for adolescents to make contact with Madagascar's unique biodiversity and environmental challenges $[27,28]$. The result is a generally low awareness of ecological processes and issues that threaten people and wildlife concurrently. A striking example is the illegal hunting of bushmeat (e.g., endangered lemurs and other mammals $[13,29,30])$ in many regions based on the misbelief that wildlife is free for consumption, alongside a generally low understanding of environmental laws [19,31,32].

Here, we present the first comprehensive literature review on the history and current situation of EE in Madagascar. We compile an overview of the diverse landscape of EE interventions in Madagascar and ask the question of whether EE is able to promote pro-environmental behaviors of Malagasy people and what the important determinants of success are in this process. We introduce the region of Lake Alaotra as a case study of an area that is concerned with all of the above-mentioned problems and has been the focus of a multitude of EE programs. We hope to contribute to an overdue expansion of the scientific evaluation of EE interventions.

\section{Materials and Methods}

We conducted a structured literature search using key terms and synonyms, in combination with "Madagascar" to spatially restrict the search, using Web of Science and Google Scholar search engines. Key terms included "education", "environment", "conservation", "school", "teaching", "students", "pupils", "awareness", and "development" in various combinations. This resulted in a total of 67 scientific articles and reports. Additionally, we used data compiled by Reibelt [33] and the Lemur Conservation Network (https://www.lemurconservationnetwork.org/) and expanded the database on EE interventions by utilizing the Google search engine to locate education projects by governmental and non-governmental institutions using our key terms (with a trilingual search in English, French and German). The database was temporally restricted to interventions between 2009 and the present and structured according to the site of an EE intervention and its target group (s. Supplementary Materials). Target groups were defined as administrative bodies ("officials"), school children ("students"), "teachers", or all village members regardless of their age or profession ("villagers", Figure 1). Interventions were defined as day centers that offer open libraries, computers, educational materials or meals ("center"), "environmental clubs" that engage participants in group learning, environmental festivals or movie nights that aim to raise awareness about environmental topics ("events"), organized field trips to forests or protected areas ("excursions"), contributing books, 
posters or other materials for use in EE lessons ("school material"), and EE lessons given to all target groups concerning various environmental topics ("training", Figure 1)

\section{Distribution of EE Interventions in Madagascar}

We found a total of $248 \mathrm{EE}$ interventions conducted by 41 different non-governmental organizations (NGOs) since 2009 (Table S1, Supplementary Materials). Although most of these NGOs are based abroad $(78.0 \%, 32 / 41)$, all have Malagasy counterparts that work in the respective project areas. Additionally, several governmental or intergovernmental agencies (e.g., UNICEF, USAID, US Peace Corps, Norwegian Agency for Development and Cooperation) are engaged in improving the educational infrastructure. However, their actual efforts concerning EE were difficult to determine due to their country-wide and diverse projects. We therefore restricted our analysis to interventions for which sufficient data existed to evaluate their contribution (Table S1).

Most EE interventions are associated with existing research, conservation, or restoration projects in regions adjacent to remaining forest blocks and protected areas (Figure 1). Certainly, these regions are of major importance for species conservation and limited funds of NGOs are used most effectively in areas where a conservation output can still be measured. However, some high priority areas for species conservation are still neglected by EE interventions. These are located roughly around Mananara-Nord National Park (NP), Isalo NP, Midongy-Sud NP, Andrigitra NP and Tsingy de Bemaraha NP (Figure 1). Furthermore, vast areas away from conservation hotspots are not currently targeted by EE at all.

A minority of 19.8\% (49/248) of all EE interventions were evaluated in terms of their success or the obstacles faced, and even fewer were evaluated according to scientific standards with results being published in the scientific literature. As is the case in other low-income countries [34,35], most interventions to date were implemented without any evaluation. We see a high potential for large-scale and cross-sectional evaluation of these interventions. 


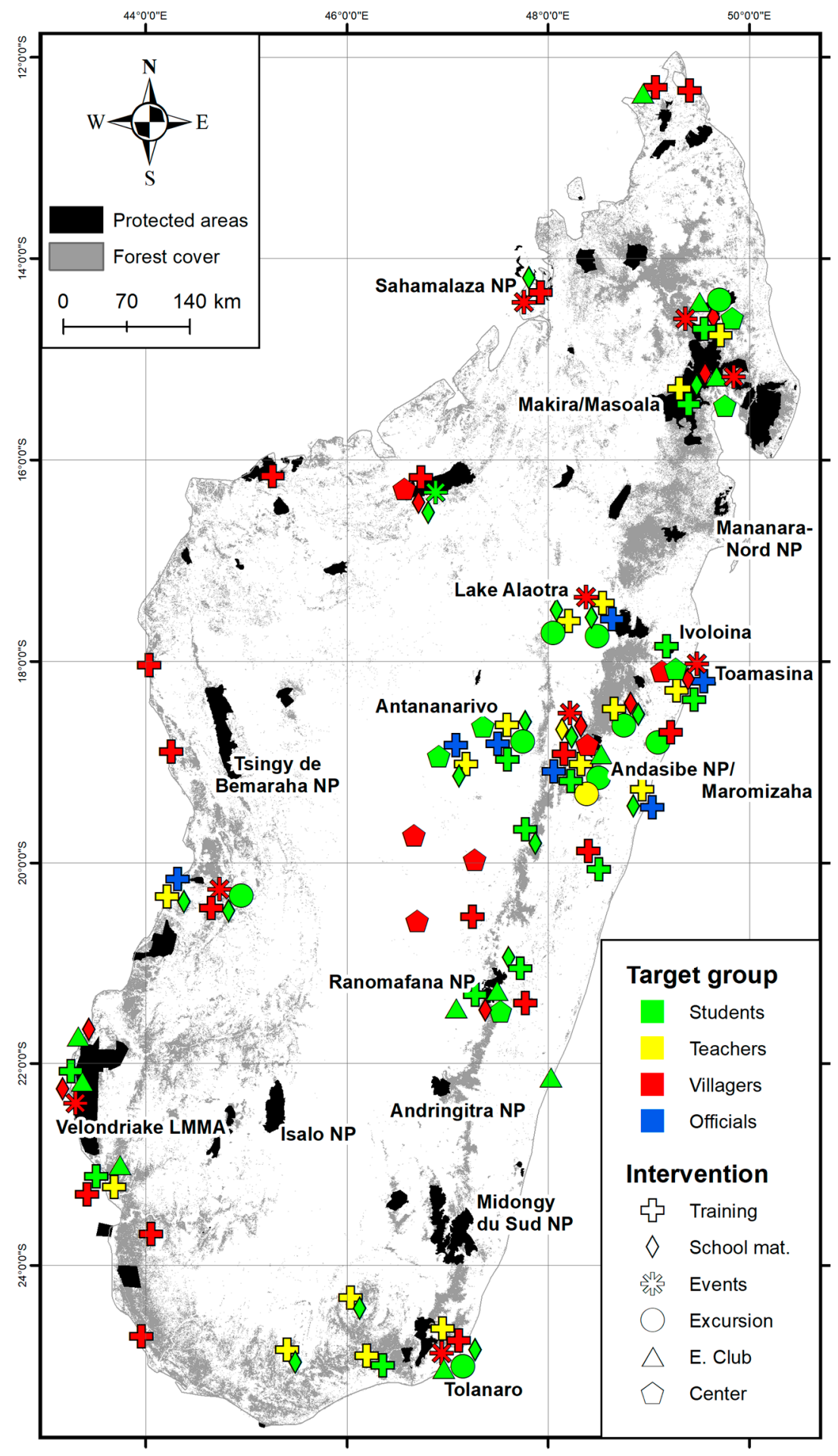

Figure 1. Distribution of environmental education (EE) interventions in Madagascar with major protected areas and remaining forest cover [36]. Overlapping symbols were dispersed over the respective location and repeated symbols per location were deleted for better visibility. For underlying data see Table in Supplementary Materials. Abbreviations: NP = national park, LMMA = locally managed marine area. 


\section{EE Interventions and Their Influence on Different Target Groups}

\subsection{Educational Determinants for Preschool Children}

EE interventions usually do not target pre-school children. However, early childhood development is the foundation for the lifelong process of learning [37,38]. For example, malnutrition disrupts the natural development of children and results in deficits concerning speaking skills and cognitive development [37,39]. The largest differences between well-nourished and mal-nourished children in a case study on three- to six-year-old children were detected at the age of six (age of school enrollment). Cognitive, language, and behavioral parameters were observed to be negatively affected [39], disadvantaging young learners right from the beginning of their formal education [37,40]. Under conditions of livelihood stress, it is quite common that only the working members of a household receive sufficient nourishment [41]. Therefore, it is not surprising that in Madagascar, almost half of all children are threatened with malnutrition today [5]. It has been repeatedly reported, that malnutrition is counteracted by the consumption of bushmeat, deriving (all too often) from endangered species $[11,13,41]$. Impaired food security therefore not only threatens biodiversity due to bushmeat hunting, it also negatively affects the nutrition and proper development of pre-school children $[9,39,41]$.

Apart from child nutrition, the socioeconomic status, wealth, and cultural context, as well as nutrition access of households, affect the school attendance rate [42-44]. For example, in some ethnic groups across Madagascar, traditional gender roles can prevent adolescents from being sent to school due to their domestic duties or fishing activities [43]. However, the education level of parents-at its most basic, knowledge about the benefits of education-can significantly improve school enrollment rates in communities that maintain traditional gender roles [42,43]. In a recent study from north-eastern Madagascar it was demonstrated that parents' attitudes towards sending their children to school have changed over the last two decades, with most interviewees referring to enabling education for their children as their main aim today [45].

\subsection{Environmental Education in Primary Schools}

Primary schools represent the only opportunity for the majority of Malagasy people to participate in formal education [25,46]. Enrollment in primary schools is about 70\% [5] and factors preventing children attending school are manifold, including malnutrition, illness, economic pressures, labor-intensive periods for households, traditional gender roles, and long distances to schools [39,42,43]. Unfortunately, drop-out rates have remained high for decades [46-48] and the mean number of years of schooling is low [5]. Today, less than $30 \%$ of the Malagasy population acquire the final grade of primary school education [5,46]. Particularly disadvantaged households require the labor of children and adolescents to sustain their livelihoods, meaning that school attendance may not be an option for most of them [43]. Street children in Antananarivo, Madagascar's capital city, were mostly deprived of any formal education due to economic activities and begging to secure their survival [49]. In some rural areas, more than half of the weekly time expenditure is dedicated to food acquisition [41], and households with fewer inhabitants are more vulnerable to internal or external stressors [50,51]. These so- called "shocks" consistently provoke a transition from school to work for adolescents and are primarily triggered by financial losses, diseases, death of family members [50], or extreme weather conditions [51]. Another major reason for considerably high drop-out rates can be found in the limited access to responsible family planning and contraceptives (e.g., condoms), promoting early childbearing and subsequently the drop-out of girls from the educational system [52,53]. However, school attendance alone does not necessarily ensure learning and the acquisition of basic reading and writing skills [54].

Therefore, most of the identified EE interventions (approximately 48.8\%,121/248) target school children. Although the first programs were already initiated in the 1980s, when providing conservation education in primary schools was part of the process of founding the Ranomafana NP [55], EE is still not, or is only marginally, implemented in the official Malagasy school curriculum $[25,27,28]$. The reasons for this may be complex, with political instability acting as one explanation [56]. Where EE takes place 
in the classroom, its outcomes can obviously be hampered by using inappropriate teaching materials. For example, two research teams reported independently, from two rural regions, that school children saw air pollution as a major environmental problem $[25,57]$. Since factories were completely absent and individual transport was virtually absent, these findings can only be explained by the use of textbooks originating from Europe. Even students who attended school until reaching the final grade often did not engage with any, or only a few, environmental or biodiversity issues and with Madagascar's unique flora and fauna at all $[25,27]$. This imbalance was first noticed by nature conservation-oriented NGOs that have tried since the 1980s to distribute educational materials to schools to supplement the regular curriculum and to strengthen their conservation efforts with a complementary educational approach [55].

In 2005, a collaboration between the École Normale Supérieure (ENS) in Antananarivo, the Durrell Wildlife Conservation Trust (Durrell), and GERP (Groupe d'Etude et de Recherche sur les Primates de Madagascar) initiated the Ako book project [48]. The books were artistically illustrated and bilingual (Malagasy and English) to be particularly useful for promoting in language lessons. The books were distributed on a country-wide scale and accompanied by educational posters so that a large number of students should be reached who only had limited contact with books in their everyday lives [48].

Dolins et al. [48] evaluated the effectiveness of the first Ako book, about Ako the Aye-Aye (Daubentonia madagascariensis). Most students liked the book because of its colorful illustrations. However, knowledge about conservation of the Aye-Aye varied considerably between schools and areas, mainly due to the distance to remaining forests and the lack of opportunity to know about these animals in their everyday lives [48]. Despite the visual appeal of the Ako book, the communication of conservation messages was insufficient due to the lack of teacher knowledge on how to use the supplementary material properly [48]. The Ako book project may have not reached its full educational potential when supplying untrained teachers with new teaching materials. To enhance the effectiveness of supplementary materials, existing teacher training by GERP and ENS required drastic expansion [48]. In addition, the Aye-Aye may have been an especially poor choice for the wish from a Western perspective to transmit a conservation message, as Rakotomamonjy et al. [19] reported that during their EE intervention in Eastern Madagascar almost all children and parents described this animal as "scary" and cared less for its continued survival than for that of other lemur species. This is rooted in traditional Malagasy beliefs seeing the Aye-Aye as a harbinger of evil [58]. Furthermore, the distribution of books as supplementary schooling material is a costly intervention. For example, McGuire et al. [59] reported that for 350 books with 135 pages (including design, print, shipment, distribution, and community events to increase acceptance) a total of US $\$ 6000$ was spent, equaling an effective cost of US\$17.1 per book. However, the authors concluded that this money was well-spent according to the success of the project in raising awareness and reducing lemur hunts, at least in the short term.

The effective use of EE materials in teaching strongly depends on teachers' skills to properly transmit the conservation message behind the material [48,54,60-62]. In general, only $17 \%$ of the teachers in primary schools are trained to teach [5], and Ormsby [63] identified insufficient teacher training in EE as a major hindrance for teachers to use the EE materials provided in schools on the Masoala peninsula. Balestri et al. [61] conducted four consecutive two-hour EE interventions with rural teachers from south-east Madagascar (around Tolanaro, Figure 1). These lessons included presentations of local topics on forests, lemurs, and the importance of an intact ecosystem combined with discussions and evaluations of the knowledge gained. As a result of this straightforward approach, targeted teachers retained environmental knowledge over at least one year, supposedly leading to increased transmission of pro-environmental knowledge to school children. However, this study lacked a control group [61]. Although 14.1\% (35/248) of all EE lessons were given to teachers to improve their pedagogical skills for subsequent EE lessons, several target areas for EE in Madagascar still lack teacher training as a supporting measure for proper communication of environmental topics (Figure 1).

Teaching performance is additionally hampered by low rates of teacher attendance in schools and high teacher-student ratios in many low-income countries (e.g., $[5,54,64])$. In their sample, 
Reibelt et al. [25] found an average class size of 49 students and a maximum of 92 children per class in the Alaotra region whereas the Malagasy average is about 42 students per class [5]. Teachers facing large classes rely mostly on ex-cathedra teaching instead of using more activating teaching methods [25]. In Madagascar, low salaries and an ineffective system of payment combined with job insecurity, and the lack of basic infrastructure and teaching materials negatively influence teachers' job satisfaction and their motivation to go to work [64-66]. To worsen this situation, only a limited percentage, especially of rural teachers, receive a salary from the state and salaries often have to be augmented by parents or are paid completely by them [25]. The security of being paid by parents increased teacher attendance and successful schooling, resulting in all but one student of the same cohort from three secondary schools from Maromizaha (Figure 1) passing their final primary school examinations [67].

EE lessons given to school children can have strong effects on environmental awareness and attitudes. Comparing two primary schools within the same rural village near Ranomafana NP (Figure 1), of which only one included EE in their curriculum, Korhonen and Lappalainen [57] demonstrated that only students from the school including EE mentioned erosion (locally present) as an environmental problem even though all the children grew up in the same environment. In contrast to the other school, students were able to offer explanations and possible solutions to this mostly man-made problem [57].

\subsection{Extracurricular Activities in EE}

Apart from primary school education, $11.3 \%$ (28/248) of all EE interventions supplement the formal school curriculum. These approaches either aim at offering additional lessons to improve students' school performance (e.g., in the final in examinations) or support interested students in participating in environmental organizations or clubs.

The Madagascar Fauna Group (MFG), for example, initiated so-called "Saturday schools" at Ivoloina near Toamasina (Tamatave) in eastern Madagascar (Figure 1). Every Saturday, they offered additional lessons in French, mathematics and environmental subjects to students from the surrounding schools [68]. Before the Saturday schools were established in 1994, only $4 \%$ of school children from the adjacent villages passed their final examinations [68] whereas in 2014 almost nine out of ten participants were able to attain their primary school grade [69]. According to Freeman [68], this impressive success was achieved due to the extensive pedagogical skills and knowledge of the Saturday school teacher. Therefore, a key measure during the expansion of the Saturday school network around Ivoloina was to educate teachers and to expand their pedagogical skills [69].

Besides these Saturday schools, environmental clubs offer a platform for interested students to participate in environmental management and resource use and to learn about biodiversity and species conservation [48]. In 1987, the WWF initiated the first Vintsy (Kingfisher) clubs (WWF homepage) that are still in existence today. Four years later, Vintsy magazines were printed as an additional outreach program. The network of Vintsy clubs has drastically expanded over the last few years and associations can be found all over Madagascar. The official EE and communication program of Masoala NP made successful use of environmental clubs and practical work with school and community tree nurseries [63]. Interestingly, active participation in club activities provided by NGOs (e.g., the Vintsy clubs) is becoming increasingly important for young Malagasy professionals seeking job opportunities with international employers [70]. At Ranomafana NP (Figure 1), the Centre ValBio also initiated "Conservation Clubs" that offered a nine-month training program to educate students about local species and the valorization of local resources. Participants were further encouraged to actively engage in resource management and reforestation activities [48]. To date, a total of 35 clubs have been established adding up to 1590 participants from all around Ranomafana National Park [71].

Similarly, so called "outdoor classrooms" targeted school classes to organize excursions into the rain forest to learn about biodiversity and forest management. In 2016/17, these outdoor classrooms had a total of 1624 participants from around Ranomafana NP [71]. This approach can have a significant impact on participants, at least in the short term, as illustrated by Patel et al. [72], who conducted 
"outdoor lessons" concerning the conservation of the critically endangered silky sifaka (Propithecus candidus) in NE Madagascar. These lessons proved effective in enhancing awareness. Whether this awareness turned into pro-environmental behaviors to help protect the silky sifaka has not been evaluated.

Another program called "Children and Trees Growing Together" aimed to supplement existing school lessons by teaching school children, together with their teachers and parents, about planting trees and restoring degraded forest habitats [48]. All 15 schools targeted with this approach established tree nurseries and started reforestation measures that are still present today [48,71]. Environmental or conservation clubs are nowadays introduced in all major EE areas of Madagascar (Figure 1), illustrating their perceived high value for EE and species conservation, although only a few of these interventions have been scientifically evaluated to date. However, Korhonen and Lappalainen [57] stated that EE was most efficient when it offered hands-on experience in addition to classroom lectures. Furthermore, students who obtained EE lessons could act as multipliers by vertically transferring knowledge to their parents [19]. In fact, parents' knowledge on environmental topics was higher in villages where school children attended an intervention, highlighting the potential to reach an even wider audience than previously thought [19].

\subsection{Implementation of EE and Environmental Sciences in Secondary and Higher Education}

Environmental education in the higher educational system in Madagascar was first realized in 1995, when a course on anthropology and primatology was offered at the University of Mahajanga [73]. From that starting point, programs on environmental sciences and education have drastically increased and today the universities of Mahajanga, Antananarivo, Toamasina and Toliara offer license, Masters or $\mathrm{PhD}$ programs in environmental sciences. Furthermore, several technical colleges have integrated programs on agronomics and educational sciences, and university teachers such as Dr. Hantanirina Rasamimanana provide courses in EE and education for sustainable development (ESD) at university level in teacher training (e.g., Ecole Supérieure de Sciences Agronomique and Ecole Normal Supérieure in Antananarivo, Institut Supérieur de Sciences, Environnement et Développement Durable ISSEDD at Toamasina University). In particular, the training of future teachers has a high potential to spread the ideas of EE in the Malagasy educational system. However, these programs are out of reach for the majority of Malagasy people. Nevertheless, an extensive community of Malagasy researchers in environmental sciences is growing. Today, Malagasy students and senior researchers are participating in almost every research project conducted in Madagascar. Experiences during higher education such as excursions or contact with international researchers have proved especially significant for the choice of occupation of Malagasy conservationists and environmental educators [28].

\subsection{EE Interventions Targeting Adults}

The first step towards EE for adults is often to raise awareness about local biodiversity and related issues. In Madagascar, the earliest approaches date back to the late 1980s and followed a rather "Western" rationale of thinking by implementing informal EE into existing zoological gardens. In 1988, the Madagascar Fauna Group in collaboration with Duke University Primate Center and the Malagasy Department of Water and Forest took over management of the Parc Zoologique Ivoloina (near Toamasina, Figure 1) to re-build the old zoological and botanical garden, exhibiting native species, combined with the establishment of an education center for local communities and tourists [74,75]. One year later, the World Wide Fund for Nature (WWF) started an EE center at the Botanical and Zoological Garden of Tsimbazaza in Antananarivo [76,77]. To date, the success and outreach of these early approaches have not been evaluated. However, zoo-based education may struggle with reaching a wider audience when implemented in a cultural setting that is not used to this kind of venue. However, entrance fees for Malagasy people are comparably low (e.g., 500 Ariary (US\$0.14) for Tsimbazaza Zoo and 1000 Ariary (US\$0.28) for adults for Parc Zoologique Ivoloina) and today the Tsimbazaza Zoo especially is often frequented by locals (personal communication, J.H. Ratsimbazafy). 
In 1997, a more culturally appropriate approach was initiated by the Durrell Wildlife Conservation Trust (Durrell) by celebrating Madagascar's unique nature with the first "Festival of the Marshes" (Malagasy name: "Fetin'ny Zetra") at Lake Alaotra. The festival offered a public platform for school competitions and collective ceremonial praying, as well as a theater play $[75,78]$. The latter focused on an old legend in which the water in the lake represents the source of life for all animals, plants, and humans around the lake. By abusing the natural resources, destroying marshes, or killing animals the natural environment will become a hostile place, therefore conservation and careful management of the marshes should be promoted (for the entire story see [78] page 165). The main objective of this informal approach was to allow communities to exhibit their local culture and traditions in terms of important regional environmental issues. Furthermore, this approach focused on a broad opportunity to participate, either as actors or as audience members and the primary use of oral skills for communication, due to high illiteracy rates in the region $[75,78]$. An evaluation of this informal approach revealed that theater especially was an effective tool for EE [78]. The awareness of environmental issues concerning degradation of the marshes was already high, but it required the festival of the marshes to motivate local communities to manage the ecosystem in a pro-environmental way [75].

By taking over these ideas, GERP in collaboration with national governmental institutions, zoos and NGOs initiated the "World Lemur Festival" in 2014 to raise awareness about lemurs and to celebrate the endemic lemur diversity on a nationwide scale. Since then, the festival has been celebrated annually throughout Madagascar and zoological institutions all over the world. However, none of the above approaches have been evaluated for their effectiveness.

Another way of raising awareness is based on the inclusion and participation of local communities in resource management. For example, participatory approaches for environmental monitoring are implemented at Lake Alaotra (see Section 5) and the Centre ValBio (Figure 1; [71]). At Ivoloina, MFG environmental groups or clubs are not only for school children but rather are open for all people who are interested in managing the ecosystem and learning about new methods of farming practice [68,79]. Concurrently, a model station for agricultural practices was established to teach more effective and sustainable farming techniques [68]. Opinions on these programs at Ivoloina were predominantly positive and they succeeded in reaching MFG's main goal of raising awareness about environmental issues [79]. However, most respondents to interviews and questionnaires were not able to identify the main objectives of the education programs, indicating that a clear statement about this was absent [79].

A social marketing campaign was used by Blue Ventures and Rare Conservation to stop destructive fishing practices within the Velondriake locally managed marine area, SW Madagascar (Figure 1; [80]). The campaign made use of local laws ("dina") to strengthen adherence of the fishers to fishing laws forbidding destructive practices and used diverse outreach methods to reach the target audience. Furthermore, these campaigns were supported by celebration ceremonies that were aiming at increasing the local value of the dinas by sanctifying the locally protected area [81]. An evaluation one year after the campaign showed improved knowledge and positive attitudes about dina. The enforcement of dina increased and destructive fishing methods decreased moderately [80]. However, the campaign costs to target these fishing villages alone were quite high at approximately US $\$ 40,000$, excluding costs for the campaign design, implementation and evaluation. In contrast, Westerman and Gardner [81] concluded that the use of ceremonies to further value the locally protected areas were worthwhile concerning their input costs of about US $\$ 500$ per ceremony. Overall, the authors proved, in one of the few evaluated EE interventions in Madagascar, the suitability of social marketing for fostering behavior change within communities of rural resource users [80].

Although the use of local taboos ("fady") and dinas are reported as useful tools by several authors [80-83], the value of these traditional community laws has been eroding recently due to increasing domestic migration and the loss of the local rooting $[29,80]$. This problem of disregard for local customs, that themselves were put in effect to ensure sustainable resource use, is repeatedly reported by conservation practitioners throughout Madagascar. 
Awareness of environmental issues can furthermore be raised in various other ways; especially in rural areas, local radio stations and broadcasting—or more recently podcasts—can be used to provide information about local environmental topics, management, or species protection [71,77]. Furthermore, several NGOs use film nights to show documentaries. Durrell used regional radio and TV stations to promote their village festivals during the participatory monitoring competition from the start of the program to increase its outreach [84]. People traveling by public transport are the target group of a cooperation between GERP and the tour operator "Cotisse" that runs all main routes along the national roads—RN2, RN4 and RN7—between Mahajanga, Toamasina, Antananarivo, Fianaratsoa and Morondava. During journeys, the movie "Bandro: The Hidden Treasure of Lake Alaotra" is shown on on-board television screens. This film, that was produced by GERP and released in February 2017, illustrates the environmental problems of Madagascar's most important rice production area (Lake Alaotra) and the difficult search for the critically endangered Alaotra gentle lemur (Hapalemur alaotrensis; personal communication, J.H. Ratsimbazafy).

\section{Limits of EE in Promoting Pro-Environmental Behaviors in Low-Income Countries: The Case of Lake Alaotra}

In this section, we further focus on developments around Lake Alaotra (Figure 1) to illustrate which factors are still preventing pro-environmental behaviors in a large rural population. Due to prolonged scientific activities by various NGOs and research groups, such as our own research group on ecology and EE at the University of Hildesheim, the published record is especially good for this region, making Lake Alaotra a valuable case study for EE, with significant implications for other low-income countries.

\subsection{Environmental Situation at Lake Alaotra}

Lake Alaotra and its surrounding fresh-water marshes (the typical wetland vegetation of the area) is the largest wetland complex in Madagascar; it represents the country's biggest inland fishery and is an important rice granary area, producing approximately 300,000 tons of rice per year [85-87]. Lake Alaotra has been legally protected as a Ramsar site since 2003 and by national law as a Nouvelle Area Protégé (NAP) since 2007. However, human needs collide with biodiversity conservation and ecosystem functioning in this region. Livelihoods mostly depend on smallholders cultivating rice and vegetables and family-based fishing activities [88-90]. Even if conditions for making a livelihood are harsh, they are nonetheless still above the Malagasy average, leading to a massive population influx, with approximately 110,000 inhabitants in 1960 [91] to over 560,000 inhabitants currently [90]. Human pressure on land and resource overuse have led to a nexus of interlinked problems including deforestation and erosion, siltation of agricultural lands, declining harvests, marsh fires, land conversion into rice fields, overfishing and declining catches, spreading of invasive fish and plant species, and a decline in the general ecological state of the lake [14,84,90,92-95]. This ongoing degradation is found in most of Madagascar's wetlands [96]. The native endemic flora and fauna of Lake Alaotra and its marshes are also threatened due to these human-made pressures. Considering waterfowl as an example, the Alaotra grebe (Tachybaptus rufolavatus) has already been declared extinct, the Madagascar pochard (Aythya innotata) is in steep decline and lost from Lake Alaotra, and Meller's Duck (Annas melleri) is listed as threatened [97]. Additionally, the critically endangered Alaotra gentle lemur (Hapalemur alaotrensis) or Bandro (the vernacular name) is one of the most threatened primates in the world. This locally endemic species is restricted to the marsh belt of Lake Alaotra and is, therefore, especially sensitive to marsh conversion into agricultural land, human-induced marsh fires, habitat fragmentation and bushmeat hunting [98-100].

\subsection{Past EE Interventions at Lake Alaotra}

Because of its outstanding economic and ecological importance (see above), the Lake Alaotra region has received much attention from state agencies and different NGOs for over twenty years now. 
EE projects have included targeting formal education in primary schools, informal approaches such as the "Festival of the Marshes", participatory monitoring of the wetlands, and community-based management of protected areas and natural resources such as fish stocks.

Durrell has been active at Lake Alaotra since 1986 and started its public awareness campaign in 1997. As is often true for Western NGOs, it started with research on endemic species as part of a species conservation program and later included EE as tool to include the local population [84]. Durrell uses participatory and educational approaches in a wide sense, including stakeholder meetings and workshops, participatory ecological monitoring including an inter-village competition, initiating and supporting local grass-root initiatives in marsh conservation, training of local tourist guides, and awareness campaigns such as environmental quizzes during village meetings as well as EE in local schools. The value of intact marshes for people's livelihoods and wildlife alike should be transmitted by pointing out their services to the ecosystem [84,87]. Durrell was involved in the elaboration of management plans and the establishment of community-based protected areas such as the "Parc Bandro", a protected area of approximately 85 ha that is the refuge of the largest remaining population of H. alaotrensis. During the last monitoring campaign in 2008, family groups of this primate were larger, more frequently encountered, and more docile which was attributed to local community management contributing to conservation efforts [101]. As a result, monitoring of the marshes showed a decline in marsh fires during the period 2000-2003 and greater environmental knowledge and awareness were correlated with improved environmental management by resource users [84].

Madagascar Wildlife Conservation (MWC) uses ecotourism and thereby the non-consumptive valorization of nature for local communities, awareness campaigns and EE [102]. MWC started to distribute comic books on environmental topics to primary schools around Lake Alaotra in 2006 [47]. Based on typical cultural elements from the region, these comic books aimed to explain the main environmental issues such as slash-and-burn agriculture, lemur hunting and the importance of the marsh ecosystem for local species and livelihoods [47,48]. Starting with four primary schools, the project was expanded to 12 schools around the lake in 2013 and its outcomes evaluated by Richter et al. [60]. A comparison of questionnaire scores of school children before, directly after, and one year after lessons using the comic books revealed that environmental knowledge was significantly increased. The usage of additional hands-on materials to promote interactive peer-to-peer learning led to the highest test scores in comparison to control groups [60]. A crucial measure for successful interventions was teacher training conducted prior to the lessons using the comic books, since training in conducting EE does not normally take place during teacher training [25,48,60]. Interviews with people from Andreba, where MWC's cooperation with primary schools started and Parc Bandro is located, show a high awareness of the importance of the marshes for livelihoods and wildlife, and benefits for the park community [103], however, other research showed a less favorable picture with incomes generated by illegal activities within the park - mostly rice planting, carried out by members of its local governing body, the VOI (vondron' olona ifotony) responsible for the community management of Parc Bandro since 2001—exceeding by tenfold the benefits from legal activities such as ecotourism [104].

The Alaotra Marshland Biodiversity research project (AMBio) of the University of Hildesheim started at the end of 2012 and addressed the nexus of biodiversity conservation, local livelihoods and EE. A major finding was that Malagasy teachers' definition of EE differed from that given by UNESCO. The teachers' focus lies in the social aspects emerging from environmental change rather than on the degradation of the natural environment. For example, invasive introduced fish species such as Channa spp., that very likely played a major role in the extinction of waterfowl and the endemic fish species of Lake Alaotra, were seen as beneficial by a large group of teachers because of their contribution to the protein supply and cash income [25]. In consequence, this led to different objectives for EE by Malagasy teachers and those Western NGOs financing EE, thereby causing friction. GERP and several other international, regional, and local NGOs are also active in the area, but their input to EE remains unclear. 


\subsection{Lessons Learned and Major Obstacles}

Overall, the Alaotra region case study showed that even various and decade-long EE interventions targeting a multitude of stakeholder groups and using different educational approaches have had only a limited impact. First of all, against the backdrop of a steady increase in the human population and human pressure on land, the EE programs provided by NGOs only reached a very limited fraction of the population and resource users. MWCs comic book project reached out to fewer than twenty schools from over 700 primary schools in the region. This comes out, at best, as some thousand students from a student population estimated at more than 115,000 in 2012 [25]. From the approximately 3300 teachers, only a small fraction could be trained in EE by NGOs like MWC over the years [102]. In addition, teachers in rural Madagascar and the Alaotra region were underpaid and under-educated, and therefore often limited in their pedagogical capacities. In particular, insufficient and irregular payment led to teachers' demotivation and the necessity of holding second jobs [25]. Secondly, limited funding for campaigns by donors mostly led to temporary projects, short-time interventions and limited outreach.

Moreover, teacher training by specialists, the printing of comic books, and additional single-use materials and their distribution in the field are costly: the cost of one comic book was approximately US $\$ 1.1$ and the cost of single-use materials was US\$1.0. Over the years, MWC gave away some thousand comics at a limited number of schools but expansion of its campaign was restricted by limited funding [60,102]. In a way one could argue that the better substantiated the intervention, the costlier it becomes and the shorter period it can be financed by a given NGO. To avoid any misunderstandings, NGOs can provide valuable input to EE, but they are too weak, both financially and in their legal position, to substitute for the education responsibilities of the state. Often there is also no strategy for program continuation after funding ends. Here, a solution can be to design EE programs from the beginning in a locally meaningful and culturally sensitive way with project participation by the target population $[25,47]$. The often missing, or only short period, financed by donors for the improvement of projects or the evaluation of program results is another major problem for improving EE. The evaluation of MWC's comic book project was only made possible by an additional grant from the European Association of Zoos and Aquaria (EAZA) Madagascar Campaign 2010 and could not have been carried out with the grant for the original comic book project. The AMBio project proved the suitability of the invasive water hyacinth (Eichhornia crassipes) compost as a sustainable, cheap, and eco-friendly alternative to inorganic fertilizer, especially for smallholder farmers. However, for an area-wide implementation, long-term funding would be necessary.

Thirdly, despite all educational interventions, the growing human population and the resulting pressure on resources in combination with social and climate change, and a deteriorating environment, result in people losing their assets and being exposed to diverse stressors and shocks, leaving them with fewer livelihood choices [94]. In a population where livelihood insecurity is the norm, hunger a steady companion, and the ability to withstand external shocks limited, choices are made on a short timeframe to solve imminent problems and not the overarching environmental problems on the horizon [85]. In particular, smallholder farmers, such as those in the Alaotra region, have been found to be extremely vulnerable to agricultural risks and climate change in Madagascar [105]. In their study, Borgerson et al. [9] reported a high prevalence of child malnutrition in the Alaotra region; $98 \%$ of households reported food insecurity, and regular food restriction for non-working household members were encountered in $47.3 \%$ of surveyed households. Even if the overall level of (mostly illegal) wildlife hunting was generally low, the least food-secure households supplemented their diet with mammals, mostly tenreks, but one out of thirty households had also eaten Hapalemur alaotrensis within the last year. Resource users often know about the detrimental effects of their customs, such as using mosquito nets for fishing, in the long run. However, their living conditions force them towards choices tackling their most pressing daily problems, such as food insecurity, at the expense of the long-term viability of the whole human-environmental system. Durrell reported on bringing the number of marsh fires down by participatory environmental monitoring. However, this only seems to be true for a limited 
period, as stronger drivers such as the lack of law enforcement during the political crisis starting in 2009, and powerful outside players driving marsh conversion into rice fields for trade intensification, led to an increase of burning in the period starting 2013 and a reported reduction of the H. alaotrensis habitat from 9400 ha to 5800 ha between 2001 and 2007 alone [87,100,102]. Even in an ordinary village of approximately 4000 inhabitants like Andreba targeted by international NGOs such as Durrell, MWC, and GERP and with active local associations such as the VOI and Zetra Maintso, overall knowledge of protected areas such as Parc Bandro and environmental regulations remains low, and likewise compliance with them $[103,104]$.

In addition, one has to keep in mind that people under constant threats to their livelihood tend to be conservative in their choices to avoid additional risks arising from new methods and behaviors. This further limited the probability that innovations from EE would be implemented by resource users. Adaptation to change is described as reactive rather than proactive or cannot be undertaken at all due to the limited resources and capacities of smallholders $[94,105,106]$. This risk-averse behavior can in principle be overcome by safeguarding the target group of a given EE intervention from the possible negative consequences of the perceived risks, thereby making the intervention even more costly as a side-effect [90].

\section{Conclusions}

A lack of knowledge remains the main reason preventing people from becoming pro-active in environmental conservation [28]. Therefore, raising awareness and building knowledge of environmental issues is a first major step towards pro-environmental behaviors. In Madagascar, this has been addressed through celebrating environmental festivals and ceremonies [75,81,107], theater [78], producing pro-environmental radio programs [71,72,77], and conducting participatory environmental monitoring [71,84]. Other approaches focused on supplementing formal education with EE lessons or materials such as comic books $[47,48,59,60,108,109]$, teacher training $[48,60,61,68]$, environmental clubs, Saturday schools, participation in restoration projects $[48,68,69]$, social marketing campaigns [80], ecotourism, and sustainable resource management (Figure 1; [31,110]). Table 1 summarizes the main obstacles for to encouraging pro-environmental behaviors in Madagascar and the use of targeted interventions (mainly EE) as scientifically sound solutions within the context of many low-income countries like Madagascar.

As we have shown, all of the above-mentioned EE interventions are conducted by international, national or local NGOs because EE is still not implemented in the Malagasy school curriculum. Major constraints for providing EE repeatedly reported by practitioners are extensive costs for staff, training, education campaigns and materials $[59,60,63,80,81]$. We further illustrated, with Lake Alaotra as a case study region, that NGOs are reaching their limits in implementing EE within any given context as long as governmental organizations and the state themselves do not provide sufficient funding for education; so that currently, restricted funds for NGOs strongly limit the coverage for any EE intervention.

Although only a few EE interventions have been scientifically evaluated so far, our review provides several promising insights. The majority of EE interventions have been conducted with school children and in particular, topic-specific teacher training prior to EE lessons was identified as a key for successful implementation. Properly trained teachers, as well as students who attended the respective lessons, have been shown to act as multipliers in transmitting environmental knowledge, even reaching out to student's parents [19]. Extra-curricular activities such as environmental clubs are today implemented widely in parts of Madagascar, indicating their perceived high value by implementation stakeholders. 
Table 1. Major obstacles for encouraging pro-environmental behaviors outlined in this review with scientifically evaluated and successful solutions within the Malagasy context.

\begin{tabular}{|c|c|c|c|}
\hline Obstacles & Example & Solution & Ref. \\
\hline Child malnutrition & $\begin{array}{l}\text { Malnutrition disrupts proper } \\
\text { cognitive development of } \\
\text { pre-school children }\end{array}$ & Improvement of food security & {$[37,39]$} \\
\hline External shocks & $\begin{array}{l}\text { Lead to hunger periods and } \\
\text { reduction of calorie intake }\end{array}$ & $\begin{array}{l}\text { Improvement of food security, social } \\
\text { security measures }\end{array}$ & {$[41,50,51]$} \\
\hline Traditional gender roles & $\begin{array}{l}\text { Can prevent school attendance } \\
\text { due to domestic duties }\end{array}$ & $\begin{array}{l}\text { Measures highlighting benefits from } \\
\text { education for children, } \\
\text { especially girls }\end{array}$ & [43] \\
\hline $\begin{array}{l}\text { Low perceived benefit from } \\
\text { education }\end{array}$ & $\begin{array}{l}\text { Parents perception of } \\
\text { education can prevent school } \\
\text { attendance }\end{array}$ & $\begin{array}{l}\text { Measures highlighting benefits of } \\
\text { education for children }\end{array}$ & [42-44] \\
\hline Early childbearing & $\begin{array}{l}\text { Drop-out from } \\
\text { educational system }\end{array}$ & $\begin{array}{l}\text { Information and distribution of } \\
\text { contraceptives, sexuality education }\end{array}$ & {$[52,53]$} \\
\hline $\begin{array}{l}\text { Inappropriate } \\
\text { schooling materials }\end{array}$ & No, too few or old textbooks & $\begin{array}{l}\text { Provision of schooling material, } \\
\text { e.g., with integrated EE (Ako book } \\
\text { project, MWC comic book } \\
\text { project etc.) }\end{array}$ & {$[25,57]$} \\
\hline $\begin{array}{l}\text { Inappropriate } \\
\text { schooling content }\end{array}$ & $\begin{array}{l}\text { Use of ill-suited content } \\
\text { concerning local cultural } \\
\text { setting (e.g., use of scary } \\
\text { Aye-Aye as a flagship species) }\end{array}$ & $\begin{array}{l}\text { Use of locally meaningful and } \\
\text { adapted materials (e.g., } \\
\text { marsh-based EE materials at Lake } \\
\text { Alaotra, valued lemur species) }\end{array}$ & $\begin{array}{l}{[27,47,48,58,} \\
\quad 60,75]\end{array}$ \\
\hline $\begin{array}{l}\text { Limited abilities of teachers to } \\
\text { transmit EE message }\end{array}$ & $\begin{array}{l}\text { Inappropriate use of } \\
\text { supplementary } \\
\text { schooling materials }\end{array}$ & $\begin{array}{l}\text { Teacher training prior to } \\
\text { EE interventions }\end{array}$ & {$[48,54,60-62]$} \\
\hline $\begin{array}{l}\text { Low rates of } \\
\text { teacher attendance }\end{array}$ & $\begin{array}{l}\text { Low job satisfaction and } \\
\text { motivation to work, } \\
\text { insecure payments }\end{array}$ & $\begin{array}{l}\text { Ensuring payment of salaries } \\
\text { (often done by parents) }\end{array}$ & {$[5,25,54,64-67]$} \\
\hline High student-teacher ratios & $\begin{array}{l}\text { Mean ratio is } 42 \text { in Madagascar } \\
\text { (max: } 92 \text { students) }\end{array}$ & $\begin{array}{l}\text { Recruitment of further teachers by } \\
\text { securing salaries }\end{array}$ & {$[5,25]$} \\
\hline $\begin{array}{l}\text { Low ratio of } \\
\text { graduating students }\end{array}$ & $\begin{array}{l}\text { High failure in passing final } \\
\text { examinations even in } \\
\text { primary schools }\end{array}$ & $\begin{array}{l}\text { Supplementary schooling such as } \\
\text { Saturday schools at Ivoloina }\end{array}$ & [67-69] \\
\hline $\begin{array}{l}\text { Low participation in } \\
\text { environmental management }\end{array}$ & $\begin{array}{l}\text { Missing opportunities and } \\
\text { infrastructure to become active } \\
\text { in resource management }\end{array}$ & $\begin{array}{l}\text { Establishment of environmental } \\
\text { clubs like those at Centre ValBio or } \\
\text { the Vintsy clubs }\end{array}$ & {$[48,63,71]$} \\
\hline $\begin{array}{l}\text { Low awareness about } \\
\text { environmental issues }\end{array}$ & $\begin{array}{l}\text { Lack of knowledge on } \\
\text { environmental laws, improved } \\
\text { farming techniques etc. }\end{array}$ & $\begin{array}{l}\text { Raising awareness using multiple } \\
\text { interventions: World Lemur } \\
\text { Festival, podcasts, movie nights, } \\
\text { talent shows, sports } \\
\text { competitions, theater }\end{array}$ & {$[19,31,32]$} \\
\hline $\begin{array}{l}\text { Low compliance with } \\
\text { protected areas }\end{array}$ & $\begin{array}{l}\text { Illegal resource extraction, } \\
\text { unsustainable resource use }\end{array}$ & $\begin{array}{l}\text { Strengthening of existing local laws } \\
\text { and sanctifying of local } \\
\text { protected areas }\end{array}$ & {$[80,81]$} \\
\hline
\end{tabular}

A crucial point for the success of any EE intervention in a culturally diverse country like Madagascar is area-specific, culturally rooted, and therefore locally meaningful education materials. This can be achieved by co-developing participatory interventions with local stakeholders such as teachers, school authorities, resource users, or village leaders. NGOs should refrain from simply imposing their values and supposed solutions to environmental problems on local people. In particular, the use of characteristic species such as lemurs as flagship species for EE proved worthwhile in various local settings $[27,48,75,107]$.

To conclude, environmental education in Madagascar today entirely depends on efforts made by international or national NGOs. Some promising approaches were highlighted within this review (see Table 1), but whether the long-term goals of EE can be met remains unclear to date. However, 
encouraging pro-environmental behavior in many low-income countries such as Madagascar does not depend on sufficient knowledge about environmental issues and sustainable alternatives alone. In cases where even basic needs for infrastructure and livelihood security cannot be ensured, people are severely restricted in their choices and are often forced to make unsustainable decisions on a daily basis.

Supplementary Materials: Supplementary Table S1 is available here http://www.mdpi.com/2071-1050/11/11/3148/s1. The table gives detailed information on the $248 \mathrm{EE}$ interventions to which we refer throughout this review and, furthermore, contains the underlying data for Figure 1.

Author Contributions: The authors contributed in the following manner to this review article: Conceptualization, D.S., T.R., and J.M.-C.; Methodology: D.S.; Validation: D.S., T.R., and J.M.-C.; Formal analysis: D.S., T.R., and J.M.-C.; Investigation: D.S., T.R., and J.M.-C.; Resources: D.S.; Data curation: D.S.; Writing-original draft preparation: D.S., T.R., and J.M.-C.; Writing-review and editing: D.S., T.R., and J.M.-C.; Visualization: D.S.; Supervision: J.M.-C.; Project administration: J.M.-C.; Funding acquisition: D.S. and J.M.-C.

Funding: D.S. received funding from the Zempelin Foundation of the "deutsches Stiftungszentrum" under grant number T0214/32083/2018/sm. The APC was provided by the University of Hildesheim. The funders had no role in the design and writing of the study.

Acknowledgments: We are thankful for the financial support of the Zempelin Foundation of the "deutsches Stiftungszentrum" under grant number T0214/32083/2018/sm and further support from the University of Hildesheim. Additional gratitude goes to Jonah H. Ratsimbazafy (GERP Madagascar), Tamby Ninha Randrianary, Andrew Kirkby (Wildlife Conservation Society) and the Lemur Conservation Network for providing valuable information and Sven Richter for language editing. This manuscript was improved by the helpful comments of three anonymous reviewers.

Conflicts of Interest: The authors declare no conflict of interest.

\section{References}

1. Myers, N.; Mittermeier, R.A.; Mittermeier, C.G.; Da Fonseca, G.A.; Kent, J. Biodiversity hotspots for conservation priorities. Nature 2000, 403, 853-858. [CrossRef] [PubMed]

2. Goodman, S.M.; Benstead, J.P. Updated estimates of biotic diversity and endemism for Madagascar. Oryx 2005, 39, 73-77. [CrossRef]

3. Wright, H.T.; Rakotoarisoa, J.-A. The rise of Malagasy societies: New developments in the archaeology of Madagascar. In The Natural History of Madagascar; Goodman, S.M., Benstead, J.P., Eds.; The University of Chicago Press: Chicago, IL, USA, 2003; pp. 112-119.

4. Urech, Z.L.; Sorg, J.-P.; Felber, H.R. Challenges for community-based forest management in the KoloAla site Manompana. Environ. Manag. 2013, 51, 602-615. [CrossRef] [PubMed]

5. UNDP. Human Development Report 2016; United Nations Development Programme: New York, NY, USA, 2016.

6. Kiefer, I.; Lopez, P.; Ramiarison, C.; Barthlott, W.; Ibish, P. Development, biodiversity conservation and global change in Madagascar. In Interdependence of Biodiversity and Development Under Global Change; Ibisch, P., Vega, A., Hermann, E., Hermann, T., Eds.; Secretariat of the Convention on Biological Diversity: Montreal, QC, Canada, 2010; pp. 58-83.

7. Styger, E.; Rakotondramasy, H.M.; Pfeffer, M.J.; Fernandes, E.C.; Bates, D.M. Influence of slash-and-burn farming practices on fallow succession and land degradation in the rainforest region of Madagascar. Agric. Ecosyst. Environ. 2007, 119, 257-269. [CrossRef]

8. Zaehringer, J.G.; Hett, C.; Ramamonjisoa, B.; Messerli, P. Beyond deforestation monitoring in conservation hotspots: Analysing landscape mosaic dynamics in north-eastern Madagascar. Appl. Geogr. 2016, 68, 9-19. [CrossRef]

9. Brook, C.E.; Herrera, J.P.; Borgerson, C.; Fuller, E.; Andriamahazoarivosoa, P.; Rasolofoniaina, B.R.; Randrianasolo, J.R.R.; Rakotondrafarasata, Z.E.; Randriamady, H.J.; Dobson, A.P.; et al. Population viability and harvest sustainability for Madagascar lemurs. Conserv. Biol. 2019, 33, 99-111. [CrossRef] [PubMed]

10. Vieilledent, G.; Grinand, C.; Rakotomalala, F.A.; Ranaivosoa, R.; Rakotoarijaona, J.-R.; Allnutt, T.F.; Achard, F. Combining global tree cover loss data with historical national forest-cover maps to look at six decades of deforestation and forest fragmentation in Madagascar. Biol. Conserv. 2018, 222, 189-197. [CrossRef] 
11. Golden, C.D. Bushmeat hunting and use in the Makira Forest, north-eastern Madagascar: A conservation and livelihoods issue. Oryx 2009, 43, 386-392. [CrossRef]

12. Schwitzer, C.; Mittermeier, R.; Johnson, S.; Donati, G.; Irwin, M.; Peacock, H.; Ratsimbazafy, J.H.; Razafindramanana, J.; Louis, E.E.; Chikhi, L.; et al. Averting lemur extinctions amid Madagascar's political crisis. Science 2014, 343, 842-843. [CrossRef]

13. Borgerson, C.; McKean, M.A.; Sutherland, M.R.; Godfrey, L.R. Who hunts lemurs and why they hunt them. Biol. Conserv. 2016, 197, 124-130. [CrossRef]

14. Lammers, P.L.; Richter, T.; Waeber, P.O.; Mantilla-Contreras, J. Lake Alaotra wetlands: How long can Madagascar's most important rice and fish production region withstand the anthropogenic pressure? Madag. Conserv. Dev. 2015, 10, 116-127. [CrossRef]

15. Waeber, P.O.; Wilmé, L.; Mercier, J.-R.; Camara, C.; Lowry, P.P., II. How effective have thirty years of internationally driven conservation and development efforts been in Madagascar? PLoS ONE 2016, 11, e0161115. [CrossRef] [PubMed]

16. Stapp, W.B.; Bennett, D.; Bryan, W.J.; Fulton, J.; MacGregor, J.; Nowak, P.; Swan, J.; Wall, R.; Havlick, S. The concept of environmental education. J. Environ. Educ. 1969, 1, 30-31. [CrossRef]

17. Tilbury, D. Environmental education for sustainability: Defining the new focus of environmental education in the 1990s. Environ. Educ. Res. 1995, 1, 195-212. [CrossRef]

18. Kassas, M. Environmental education: Biodiversity. Environmentalist 2002, 22, 345-351. [CrossRef]

19. Rakotomamonjy, S.; Jones, J.; Razafimanahaka, J.; Ramamonjisoa, B.; Williams, S. The effects of environmental education on children's and parents' knowledge and attitudes towards lemurs in rural Madagascar. Anim. Conserv. 2015, 18, 157-166. [CrossRef]

20. Johnson-Pynn, J.S.; Johnson, L.R. Successes and challenges in East African conservation education. J. Environ. Educ. 2005, 36, 25-39. [CrossRef]

21. Kuhar, C.W.; Bettinger, T.L.; Lehnhardt, K.; Tracy, O.; Cox, D. Evaluating for long-term impact of an environmental education program at the Kalinzu Forest Reserve, Uganda. Am. J. Primatol. 2009, 72, 407-413. [CrossRef]

22. Borchers, C.; Boesch, C.; Riedel, J.; Guilahoux, H.; Ouattara, D.; Randler, C. Environmental education in Côte d'Ivoire/West Africa: Extra-curricular primary school teaching shows positive impact on environmental knowledge and attitudes. Int. J. Sci. Educ. Part B 2013, 4, 240-259. [CrossRef]

23. UNICEF. Analyse Budgetaire de lEducation Nationale 2014-2018; UNICEF: New York, NY, USA, 2018.

24. Scheidecker, G.; Gernhardt, A.; Rübeling, H.; Holtmannspötter, J.; Keller, H. How young adolescents draw themselves: A comparison across three eco-social contexts in southern Madagascar. Cross-Cult. Res. 2019, 53. [CrossRef]

25. Reibelt, L.M.; Richter, T.; Waeber, P.O.; Rakotoarimanana, S.; Mantilla-Contreras, J. Environmental education in its infancy at Lake Alaotra, Madagascar. Madag. Conserv. Dev. 2014, 9, 71-82. [CrossRef]

26. Education Policy and Data Center (EDPC). National Education Profile 2014. Update for Madagascar; Education Policy and Data Center: Washington, DC, USA, 2016.

27. Ratsimbazafy, J. Lemurs as the most appropriate and best didactic tool for teaching. Lemur News 2003, 8, 19-21.

28. Reibelt, L.M.; Richter, T.; Rendigs, A.; Mantilla-Contreras, J. Malagasy conservationists and environmental educators: Life paths into conservation. Sustainability 2017, 9, 227. [CrossRef]

29. Jenkins, R.K.; Keane, A.; Rakotoarivelo, A.R.; Rakotomboavonjy, V.; Randrianandrianina, F.H.; Razafimanahaka, H.J.; Ralaiarimalala, S.R.; Jones, J.P. Analysis of patterns of bushmeat consumption reveals extensive exploitation of protected species in eastern Madagascar. PLoS ONE 2011, 6, e27570. [CrossRef] [PubMed]

30. Farris, Z.J.; Golden, C.D.; Karpanty, S.; Murphy, A.; Stauffer, D.; Ratelolahy, F.; Andrianjakarivelo, V.; Holmes, C.M.; Kelly, M.J. Hunting, exotic carnivores, and habitat loss: Anthropogenic effects on a native carnivore community, Madagascar. PLoS ONE 2015, 10, e0136456. [CrossRef] [PubMed]

31. Keane, A.; Ramarolahy, A.A.; Jones, J.P.; Milner-Gulland, E. Evidence for the effects of environmental engagement and education on knowledge of wildlife laws in Madagascar. Conserv. Lett. 2011, 4, 55-63. [CrossRef]

32. Randriamamonjy, V.C.; Keane, A.; Razafimanahaka, H.J.; Jenkins, R.K.; Jones, J.P. Consumption of bushmeat around a major mine, and matched communities, in Madagascar. Biol. Conserv. 2015, 186, 35-43. [CrossRef] 
33. Reibelt, L.M. Environmental Education Activities Madagascar. Wikiversity 2018. Available online: https: //en.wikiversity.org/wiki/Environmental_Education_Activities_Madagascar (accessed on 23 March 2019).

34. Kremer, M. Randomized evaluations of educational programs in developing countries: Some lessons. Am. Econ. Rev. 2003, 93, 102-106. [CrossRef]

35. Ferraro, P.J.; Pattanayak, S.K. Money for nothing? A call for empirical evaluation of biodiversity conservation investments. PLoS Biol. 2006, 4, e105. [CrossRef]

36. Vieilledent, G.; Gardi, O.; Grinand, C.; Burren, C.; Andriamanjato, M.; Camara, C.; Gardner, C.J.; Glass, L.; Rasolohery, A.; Ratsimba, H.R.; et al. Bioclimatic envelope models predict a decrease in tropical forest carbon stocks with climate change in Madagascar. J. Ecol. 2016, 104, 703-715. [CrossRef]

37. Grantham-McGregor, S.; Cheung, Y.B.; Cueto, S.; Glewwe, P.; Richter, L.; Strupp, B. International Child Development Steering Group. Developmental potential in the first 5 years for children in developing countries. Lancet 2007, 369, 60-70. [CrossRef]

38. Walker, S.P.; Wachs, T.D.; Grantham-McGregor, S.; Black, M.M.; Nelson, C.A.; Huffman, S.L.; Baker-Henningham, H.; Chang, S.M.; Hamadani, J.D.; Lozoff, B.; et al. Inequality in early childhood: Risk and protective factors for early child development. Lancet 2011, 378, 1325-1338. [CrossRef]

39. Fernald, L.C.; Weber, A.; Galasso, E.; Ratsifandrihamanana, L. Socioeconomic gradients and child development in a very low income population: Evidence from Madagascar. Dev. Sci. 2011, 14, 832-847. [CrossRef] [PubMed]

40. Kaila, H.; Sahn, D.E.; Sunder, N. Early Life Determinants of Cognitive Ability: A Comparative Study on Madagascar and Senegal; Institute for the Study of Labor (IZA): Bonn, Germany, 2018.

41. Borgerson, C.; Rajaona, D.; Razafindrapaoly, B.; Rasolofoniaina, B.J.R.; Kremen, C.; Golden, C.D. Links between food insecurity and the unsustainable hunting of wildlife in a UNESCO world heritage site in Madagascar. Lancet 2017, 389, S3. [CrossRef]

42. Nguyen, T. Information, Role Models and Perceived Returns to Education: Experimental Evidence from Madagascar; Massachusetts Institute of Technology: Cambridge, MA, USA, 2008.

43. Nascimento Moreira, C.; Rabenevanana, M.W.; Picard, D. Boys go fishing, girls work at home: Gender roles, poverty and unequal school access among semi-nomadic fishing communities in South Western Madagascar. Compare J. Comp. Int. Educ. 2017, 47, 499-511. [CrossRef]

44. Ravaoarisoa, L.; Randriamanantsaina, L.; Rakotonirina, J.; de Dieu Marie Rakotomanga, J.; Donnen, P.; Dramaix, M.W. Socioeconomic determinants of malnutrition among mothers in the Amoron'i Mania region of Madagascar: A cross-sectional study. BMC Nutr. 2018, 4, 6. [CrossRef]

45. Diebold, C.L. Changes of Human Well-Being in the Context of Protected Areas and Cash Crop Expansion: A Case Study on Local People's Capabilities in Two Villages in North-Eastern Madagascar. Master's Thesis, University of Bern, Bern, Switzerland, 2018.

46. UNICEF. The State of the World's Children 2017 Statistical Tables; UNICEF: New York, NY, USA, 2017; Available online: http://data.unicef.org/resources/state-worlds-children-2017-statistical-tables/ (accessed on 16 February 2019).

47. Maminirina, C.P.; Girod, P.; Waeber, P.O. Comic strips as environmental educative tools for the Alaotra Region. Madag. Conserv. Dev. 2006, 1, 11-14. [CrossRef]

48. Dolins, F.L.; Jolly, A.; Rasamimanana, H.; Ratsimbazafy, J.; Feistner, A.T.; Ravoavy, F. Conservation education in Madagascar: Three case studies in the biologically diverse island-continent. Am. J. Primatol. 2010, 72, 391-406. [CrossRef]

49. Gössling, S.; Schumacher, K.; Morelle, M.; Berger, R.; Heck, N. Tourism and street children in Antananarivo, Madagascar. Tour. Hosp. Res. 2004, 5, 131-149. [CrossRef]

50. Glick, P.J.; Sahn, D.E.; Walker, T.F. Household shocks and education investments in Madagascar. Oxf. Bull. Econ. Stat. 2016, 78, 792-813. [CrossRef]

51. Marchetta, F.; Sahn, D.E.; Tiberti, L. School or Work? The Role of Weather Shocks in Madagascar; IZA Discussion Paper; IZA Institute of Labor Economics: Clermont Ferrand, France, 2018. [CrossRef]

52. Herrera, C.; Sahn, D.E.; Villa, K.M. Teen Fertility and Labor Market Segmentation in Madagascar; African Development Bank: Abidjan, Côte d'Ivoire, 2017.

53. Almanza, C.H.; Sahn, D.E. Early childbearing, school attainment, and cognitive skills: Evidence from Madagascar. Demography 2018, 55, 643-668. [CrossRef] [PubMed] 
54. Bold, T.; Filmer, D.; Martin, G.; Molina, E.; Rockmore, C.; Stacy, B.; Svensson, J.; Wane, W. What Do Teachers Know and Do? Does it Matter? Evidence from Primary Schools in Africa; World Bank: Washington, DC, USA, 2017.

55. Wright, P.C. Primate ecology, rainforest conservation, and economic development: Building a national park in Madagascar. Evol. Anthropol. 1992, 1, 25-33. [CrossRef]

56. Randrianja, S. Love me tender-Transition vers où? Madag. Conserv. Dev. 2012, 7. [CrossRef]

57. Korhonen, K.; Lappalainen, A. Examining the environmental awareness of children and adolescents in the Ranomafana region, Madagascar. Environ. Educ. Res. 2004, 10, 195-216. [CrossRef]

58. Simons, E.L.; Meyers, D.M. Folklore and beliefs about the aye aye (Daubentonia madagascariensis). Lemur News 2001, 6, 11-16.

59. McGuire, S.M.; Sitzmann, B.D.; Herrington, K.; Day, S.R.; Ramarokoto, R.E.A.F.; Louis, E.E., Jr. Distribution of a conservation-based activity book at two primary schools near Analamazaotra Special Reserve, Madagascar. Lemur News 2009, 14, 38-41.

60. Richter, T.; Rendigs, A.; Maminirina, C.P. Conservation messages in speech bubbles-Evaluation of an environmental education comic distributed in elementary schools in Madagascar. Sustainability 2015, 7,8855-8880. [CrossRef]

61. Balestri, M.; Campera, M.; Nekaris, K.A.-I.; Donati, G. Assessment of long-term retention of environmental education lessons given to teachers in rural areas of Madagascar. Appl. Environ. Educ. Commun. 2017, 1-14. [CrossRef]

62. Conn, K.M. Identifying effective education interventions in sub-Saharan Africa: A meta-analysis of impact evaluations. Rev. Educ. Res. 2017, 87, 863-898. [CrossRef]

63. Ormsby, A. Development of environmental education programs for protected areas in Madagascar. Appl. Environ. Educ. Commun. 2008, 6, 223-232. [CrossRef]

64. Bennell, P.; Akyeampong, K. Teacher motivation and incentives in sub-Saharan Africa and Asia; Department for International Development: London, UK, 2007.

65. Glewwe, P.; Maïga, E.W. The impacts of school management reforms in Madagascar: Do the impacts vary by teacher type? J. Dev. Eff. 2011, 3, 435-469. [CrossRef]

66. Gamero Burón, C.; Lassibille, G. Job satisfaction among primary school personnel in Madagascar. J. Dev. Stud. 2016, 52, 1628-1646. [CrossRef]

67. Ratsimbazafy, J.H.; Ralison, J.; Dreyer, W.; Rajaonson, A.; Andrianantenaina, T.; Rabemananjara, Z.; Rabearison, J.; Randrianarison, R.M.; Raritahiry, S.; Randriamanantena, I. Maromizaha Rainforest ProjectHouston Zoo Annual Report 2014; Maromizaha Rainforest Project: Antananarivo, Madagascar, 2014.

68. Freeman, K. Sustainable education at a developing-world field site: Developing programs linked to conservation work in-country. Int. Zoo Yearb. 2009, 43, 113-123. [CrossRef]

69. Moore, M.; Richalet, L. MFG Annual Report 2014; Madagascar Fauna Group: Toamasina, Madagascar, 2014.

70. Andriamanga, Y. Etudier ne suffit plus! Madagascar Tribune 19-04-2016. Available online: http://www. webcitation.org/78rJ8X3jd (accessed on 3 June 2019).

71. Centre ValBio. Annual Report 2017; Stony Brook University: Stony Brook, NY, USA, 2018.

72. Patel, E.R.; Marshall, J.J.; Parathian, H. Silky sifaka (Propithecus candidus) conservation education in northeastern Madagascar. Lab. Primate Newsl. 2005, 44, 8-11.

73. Thalmann, U.; Zaramody, A. Teaching primatology at the Universite de Mahajanga (NW Madagascar). In New Directions in Lemur Studies; Springer: New York, NY, USA, 1999; pp. 249-268.

74. Welch, C. Projects at Ivoloina and Betampona in eastern Madagascar. Lemur News 1996, 2, 11.

75. Durbin, J.C. Lemurs as flagships for conservation in Madagascar. In New Directions in Lemur Studies; Springer: New York, NY, USA, 1999; pp. 269-281.

76. Lanting, F.; Jolly, A.; Durrell, G.; Mack, J. Madagascar: A World out of Time; Aperture: New York, NY, USA, 1990.

77. Grieser, R. Environmental Education and Communication (EEEC) Assessment for Madagascar; GreenCOM Report for US Agency for International Development (USAID); Academy for Educational Development: Washington DC, USA, 1994.

78. Rakotoniaina, L.; Randriamanampisoa, H. Theatre as a tool for conservation of threatened species. Dodo 1999, 35, 158-170.

79. Angiolillo, G.; Sangodkar, S.; West, N.; Wyman, N. Description and Evaluation of an Environmental Education Program in Madagascar. Master's Thesis, Duke University, Durham, NC, USA, 2012. 
80. Andriamalala, G.; Peabody, S.; Gardner, C.J.; Westerman, K. Using social marketing to foster sustainable behaviour in traditional fishing communities of southwest Madagascar. Conserv. Evid. 2013, 10, 37-41.

81. Westerman, K.; Gardner, C.J. Adoption of socio-cultural norms to increase community compliance in permanent marine reserves in southwest Madagascar. Conserv. Evid. 2013, 10, 4-9.

82. Bodin, Ö.; Tengö, M.; Norman, A.; Lundberg, J.; Elmqvist, T. The value of small size: Loss of forest patches and ecological thresholds in southern Madagascar. Ecol. Appl. 2006, 16, 440-451. [CrossRef]

83. Jones, J.P.; Andriamarovololona, M.M.; Hockley, N. The importance of taboos and social norms to conservation in Madagascar. Conserv. Biol. 2008, 22, 976-986. [CrossRef]

84. Andrianandrasana, H.T.; Randriamahefasoa, J.; Durbin, J.; Lewis, R.E.; Ratsimbazafy, J.H. Participatory ecological monitoring of the Alaotra wetlands in Madagascar. Biodivers. Conserv. 2005, 14, 2757-2774. [CrossRef]

85. Copsey, J.A.; Rajaonarison, L.H.; Randriamihamina, R.; Rakotoniaina, L.J. Voices from the marsh: Livelihood concerns of fishers and rice cultivators in the Alaotra wetland. Madag. Conserv. Dev. 2009, 4, 25-30. [CrossRef]

86. Ferry, L.; Mietton, M.; Robison, L.; Erismann, J. Alaotra Lake (Madagascar)—Past, present and future. Zeitschrift für Geomorphologie 2009, 53, 299-318. [CrossRef]

87. Ratsimbazafy, J.H.; Ralainasolo, F.; Rendigs, A.; Mantilla-Contreras, J.; Andrianandrasana, H.; Mandimbihasina, A.; Nievergelt, C.; Lewis, R.; Waeber, P. Gone in a puff of smoke? Hapalemur alaotrensis at great risk of extinction. Lemur News 2013, 17, 14-18.

88. Ducrot, R.; Capillon, A. A practice analysis to account for adoption of innovations in irrigated rice cropping systems in Lake Alaotra (Madagascar). J. Sustain. Agric. 2004, 24, 71-96. [CrossRef]

89. Wallace, A.P.C. Understanding Fishers' Spatial Behaviour to Estimate Social Costs in Local Conservation Planning. Ph.D. Thesis, Imperial College London, London, UK, 2013.

90. Rakotoarisoa, T.F.; Waeber, P.O.; Richter, T.; Mantilla-Contreras, J. Water hyacinth (Eichhornia crassipes), any opportunities for the Alaotra wetlands and livelihoods? Madag. Conserv. Dev. 2015, 10, 128-136. [CrossRef]

91. Pidgeon, M. An Ecological Survey of Lake Alaotra and Selected Wetlands of Central and Eastern Madagascar in Analyzing the Demise of Madagascar Pochard Aythya innotata; WWF/Missouri Botanical Garden: Antananarivo, Madagascar, 1996.

92. Bakoariniaina, L.N.; Kusky, T.; Raharimahefa, T. Disappearing Lake Alaotra: Monitoring catastrophic erosion, waterway silting, and land degradation hazards in Madagascar using Landsat imagery. J. Afr. Earth Sci. 2006, 44, 241-252. [CrossRef]

93. Ranarijaona, H.L.T. Concept de Modèle Ecologique pour la Zone Humide Alaotra. Madag. Conserv. Dev. 2009, 2. [CrossRef]

94. Stoudmann, N.; Waeber, P.O.; Randriamalala, I.H.; Garcia, C. Perception of change: Narratives and strategies of farmers in Madagascar. J. Rural Stud. 2017, 56, 76-86. [CrossRef]

95. Lammers, P.; Richter, T.; Mantilla-Contreras, J. From safety net to point of no return: Is small-scale inland fishery reaching its limits? submitted.

96. Bamford, A.J.; Razafindrajao, F.; Young, R.P.; Hilton, G.M. Profound and pervasive degradation of Madagascar's freshwater wetlands and links with biodiversity. PLoS ONE 2017, 12, e0182673. [CrossRef]

97. Bamford, A.J.; Sam, T.S.; Razafindrajao, F.; Robson, H.; Woolaver, L.G.; de Roland, L.A.R. The status and ecology of the last wild population of Madagascar Pochard Aythya innotata. Bird Conserv. Int. 2014, 25, 97-110. [CrossRef]

98. Mutschler, T.; Randrianarisoa, A.J.; Feistner, A.T.C. Population status of the Alaotran gentle lemur Hapalemur griseus alaotrensis. Oryx 2001, 35, 152-157. [CrossRef]

99. Ralainasolo, F.B.; Waeber, P.O.; Ratsimbazafy, J.H.; Durbin, J.; Lewis, R. The Alaotra gentle lemur: Population estimation and subsequent implications. Madag. Conserv. Dev. 2009, 1, 9-10.

100. Schwitzer, C.; Mittermeier, R.; Rylands, A.; Chiozza, F.; Williamson, E.; Wallis, J.; Cotton, A. Primates in Peril: The World's 25 Most Endangered Primates 2042-2016; IUCN SSC Primate Specialist Group (PSG) and International Primatological Society (IPS) and Conservation International (CI) and Bristol Zoological Society: Arlington, VA, USA, 2016.

101. Guillera-Arroita, G.; Lahoz-Monfort, J.J.; Milner-Gulland, E.J.; Young, R.P.; Nicholson, E. Monitoring and conservation of the Critically Endangered Alaotran gentle lemur Hapalemur alaotrensis. Madag. Conserv. Dev. 2011, 5, 102-109. [CrossRef] 
102. Rendigs, A.; Reibelt, L.M.; Ralainasolo, F.B.; Ratsimbazafy, J.H.; Waeber, P.O. Ten years into the marshes-Hapalemur alaotrensis conservation, one step forward and two steps back? Madag. Conserv. Dev. 2015, 10, 13-20. [CrossRef]

103. Waeber, P.O.; Reibelt, L.M.; Randriamalala, I.H.; Moser, G.; Raveloarimalala, L.M.; Ralainasolo, F.B.; Ratsimbazafy, J.H.; Woolaver, L. Local awareness and perceptions: Consequences for conservation of marsh habitat at Lake Alaotra for one of the world's rarest lemurs. Oryx 2017, 52, 677-686. [CrossRef]

104. Lammers, P.L.; Richter, T.; Lux, M.; Ratsimbazafy, J.H.; Mantilla-Contreras, J. The challenges of community-based conservation in developing countries-A case study from Lake Alaotra, Madagascar. J. Nat. Conserv. 2017, 40, 100-112. [CrossRef]

105. Harvey, C.A.; Rakotobe, Z.L.; Rao, N.S.; Dave, R.; Razafimahatratra, H.; Rabarijohn, R.H.; Rajaofara, H.; MacKinnon, J.L. Extreme vulnerability of smallholder farmers to agricultural risks and climate change in Madagascar. Philos. Trans. R. Soc. B 2014, 369, 20130089. [CrossRef]

106. Reibelt, L.M.; Woolaver, L.; Moser, G.; Randriamalala, I.H.; Raveloarimalala, L.M.; Ralainasolo, F.B.; Ratsimbazafy, J.; Waeber, P.O. Contact matters: Local peoples' perceptions of Hapalemur alaotrensis and implications for conservation. Int. J. Primatol. 2017, 38, 588-608. [CrossRef]

107. Volampeno, M.S.N.; Downs, C.T. Involving local communities in conservation: An example involving blue-eyed black lemurs (Eulemur flavifrons). Lemur News 2009, 14, 5-58.

108. Rakotonirina, L.H.F.; Chamberlan, C. L'education environnementale pour la conservation de Prolemur simus dans les villages environnant la forêt de Vohibe, District de Mahanoro, Madagascar. Lemur News 2014, $18,43-48$.

109. Ravaloharimanitra, M.; Ranaivosoa, L.; Chamberlan, C.; King, T. Sensibilisation a la conservation de Prolemur simus dans le district de Brickaville. Lemur News 2013, 17, 6-8.

110. Ormsby, A.; Mannle, K. Ecotourism benefits and the role of local guides at Masoala National Park, Madagascar. J. Sustain. Tour. 2006, 14, 271-287. [CrossRef]

(C) 2019 by the authors. Licensee MDPI, Basel, Switzerland. This article is an open access article distributed under the terms and conditions of the Creative Commons Attribution (CC BY) license (http://creativecommons.org/licenses/by/4.0/). 